\title{
Antidesma thwaitesianum Müll. Arg. Fruit Juice, Its Phytochemical Contents, Antimicrobial Activity, and Application in Chiffon Cake
}

\author{
Patcharaporn Tinchan $\left(\mathbb{D},{ }^{1}\right.$ Arpassorn Sirijariyawat $\left(\mathbb{D},{ }^{2}\right.$ Arunya Prommakool $\left(\mathbb{D},{ }^{2}\right.$ \\ Kriangkrai Phattayakorn $\mathbb{D}^{2}, 2$ Soukbandith Pheungsomphane $\mathbb{D}^{2},{ }^{2}$ and Chintana Tayuan $\mathbb{D}^{2}$ \\ ${ }^{1}$ Kasetsart University, Kamphaeng Saen Campus, Faculty of Agriculture, Nakhon Pathom Province, Thailand \\ ${ }^{2}$ Kasetsart University, Chalermphrakiat Sakon Nakhon Province Campus, Faculty of Natural Resources and Agro-Industry, \\ Sakon Nakhon Province, Thailand \\ Correspondence should be addressed to Chintana Tayuan; fnacnt@ku.ac.th
}

Received 27 August 2021; Revised 28 December 2021; Accepted 11 January 2022; Published 28 January 2022

Academic Editor: Severino Matias de Alencar

Copyright (C) 2022 Patcharaporn Tinchan et al. This is an open access article distributed under the Creative Commons Attribution License, which permits unrestricted use, distribution, and reproduction in any medium, provided the original work is properly cited.

\begin{abstract}
Antidesma thwaitesianum Müll. Arg. or Mao is well-known in Thailand for its use in soft drinks and wine. This study investigated the potential of its fruit juice as a food preservative based on its antimicrobial activity against food-borne pathogens and spoilage. The fruit juice had antibacterial activity against Bacillus cereus TISTR1527, Staphylococcus aureus TISTR2329, Listeria monocytogenes DMST17303, Pseudomonas aeruginosa TISTR357, Salmonella Typhimurium DMST562, and Escherichia coli TISTR074. The minimum inhibitory concentration ranged from 25 to $100 \mathrm{mg} / \mathrm{ml}$. Of significance was that the juice had excellent antifungal activities against Aspergillus flavus TISTR3135 and Penicillium digitatum ATCC10030. Furthermore, the fruit juice increased the lag time of spore germination of $P$. digitatum. Analysis of the phytochemical contents of the juice showed that the total phenolic and flavonoid contents were $20.07 \mathrm{mg}$ GAE/g and $3.57 \mathrm{mg}$ QE/g, respectively. In antioxidant activity assay, the juice exhibited moderate $\mathrm{DPPH}$ and $\mathrm{ABTS}^{+}$radical scavenging and ferric-reducing activities. The addition of $5 \%$ fruit juice extended the microbial shelf life of chiffon cake. The treated chiffon cake had a shelf-life of 7 days, compared to 3 days for the untreated control. These results support the possible use of Mao fruit juice as an antimicrobial agent and a natural food preservative.
\end{abstract}

\section{Introduction}

Antidesma thwaitesianum Müll. Arg., known as "Mao" in Thai, is in the family Phyllanthaceae which is most diverse in South-East Asia. It is a tropical fruit commonly found in Northeast Thailand [1]. Almost all parts of this plant are used for the treatment of various disease due to having cytotoxic, antidiabetic, antioxidant, antiradical, thrombolytic, antiplatelet, anticoagulant, antidysenteric, antimicrobial, antihypertensive, anticancer, and sudorific activity [2]. Mao fruit is well-known in Thailand for its use in soft drinks, wine, and healthy foods $[3,4]$. Ripe fruit is rich in 5hydroxymethylfurfural (HMF), several volatile compounds, organic acid, long-chain fatty acid, and photochromic com- pound [5]. Mao fruits have also been reported to contain phytochemicals that have great antioxidant potential [6] and provide various biological activities [2, 7]. However, the various parts of Mao fruit have differences in their phytochemical compounds. Whole fruits have confirmed the presence of phenolic compounds [4]. Furthermore, anthocyanin, flavonoids, and phenolic acid were present in the methanolic fruit extracts [8]. The main polyphenolic components in the fruits are gallic acid, (-)-epicatechin, (+)-catechin, and cyanidin-3-O-glucoside [6]. Seeds and marcs are abundant sources of polyphenols and proanthocyanidins [9]. While the fruit juice contains high amounts of several bioactive components such as phenolics, ascorbic acid, anthocyanins, and flavonoids [10-12]. Mao fruit extracts 
exhibited antimicrobial properties [13]. However, only antibacterial activity of Mao fruit extracts against a limited number of pathogens was reported $[3,4]$. There is a lack of reporting on the antimicrobial potential of the fruit juice against food-related microorganisms, especially spoilage molds. This research is aimed at evaluating the antibacterial activities of Mao fruit juice against foodborne pathogens and food spoilage microorganisms. In this work, we are reporting, for the first time, on antifungal activity of Mao fruit juice. In addition, the phytochemical contents and antioxidant activity of the fruit juice and its application in food systems were investigated. To our knowledge, no investigation has addressed the use of Mao fruit juice as a natural preservative in chiffon cake.

\section{Materials and Methods}

2.1. Test Microorganisms. Six bacterial strains and two mold strains were used in this experiment. Pseudomonas aeruginosa TISTR357, Escherichia coli TISTR074, Salmonella Typhimurium DMST562, Listeria monocytogenes DMST17303, Staphylococcus aureus TISTR2329, Bacillus cereus TISTR1527, and Aspergillus flavus TISTR3135 were obtained from Thailand Institute of Scientific and Technological Research (TISTR) cultures, and Department of Medical Sciences Thailand (DMST culture collection). Penicillium digitatum ATCC10030 was obtained from the American Type Culture Collection (ATCC, USA).

2.2. Plant Material and Preparation. The Fapratan cultivar of A. thwaitesianum Müll. Arg. was used in this study. Fresh Mao fruits were collected from Phu Phan municipality, Sakon Nakhon province, Thailand. The fruits were washed and squeezed, and the marc and seed were separated. Their juice extracts were dried using a lyophilizer at $-55^{\circ} \mathrm{C}$ under vacuum.

2.3. Antimicrobial Activity Screening. The Mao juice was screened for its antimicrobial activity against foodborne pathogens and spoilage microorganisms using the agar well diffusion method as described by Al-Zoreky [14] with slight modification. Bacterial suspension at a concentration of $10^{7} \mathrm{CFU} / \mathrm{ml}$ was inoculated on Mueller-Hinton agar (MHA) using a pour plate technique. Mold spores at a concentration of $10^{5}$ spores $/ \mathrm{ml}$ were inoculated on potato dextrose agar (PDA) plates. Wells $(6 \mathrm{~mm}$ diameter) were punched into the inoculated plates using a sterile cork borer. Each well was filled with $100 \mu \mathrm{l}$ of the juice at a concentration of $200 \mathrm{mg} / \mathrm{ml}$. Gentamycin and amphotericin B were used as positive controls for the analysis against bacteria and mold, respectively. The bacterial cultures were incubated at $37^{\circ} \mathrm{C}$ for $24 \mathrm{~h}$, while the mold cultures were incubated for 5 days at $25^{\circ} \mathrm{C}$ for Penicillium digitatum and at $30^{\circ} \mathrm{C}$ for Aspergillus flavus. Antimicrobial activity was detected by measuring the zone of inhibition (including the well diameter) that appeared after the incubation.

2.4. Determination of Minimum Inhibitory Concentrations. The minimum inhibitory concentration (MIC) is defined as the lowest concentration of an antimicrobial agent that will inhibit the visible growth of a microorganism. The MIC of Mao juice was tested using the agar diffusion method as described by Gonelimali et al. [15]. The bacterial suspension and mold spores were inoculated on MHA and PDA, respectively, using the pour plate technique as previously described. Wells $(6 \mathrm{~mm}$ diameter) were cut into the inoculated agar. Different concentrations of juice at 12.5, 25, 50, 100 , or $200 \mathrm{mg} / \mathrm{ml}$ were prepared using two-fold serial dilution. Samples (each $100 \mu \mathrm{l}$ ) of the juice were transferred to the respective wells. Gentamycin and amphotericin B were used as positive controls, with sterile water serving as the negative control. Then, each plate was incubated as described above. The growth of the respective microorganisms was observed. The MIC was considered as the lowest concentration that inhibited the visible growth of the organisms.

2.5. Determination of Minimum Bactericidal and Fungicidal Concentrations. Two lowest concentrations of the juice exhibiting invisible growth from MIC plates were tested for minimum bactericidal and fungicidal concentrations (MBC and MFC, respectively) using a broth dilution technique. Bacterial inoculum $(100 \mu \mathrm{l})$ of $10^{7} \mathrm{CFU} / \mathrm{ml}$ or spore suspensions of $10^{5}$ spores $/ \mathrm{ml}$ were mixed with $200 \mu \mathrm{l}$ of antimicrobial juice to produce a final inoculum of approximately $10^{6}$ $\mathrm{CFU} / \mathrm{ml}$ of bacterial cultures or $10^{4}$ spores $/ \mathrm{ml}$ of mold spores. After 16-18h, the tested suspensions were spread on agar (MHA or PDA) plates and incubated as previously described. The concentration of the juice causing negative growth of bacteria and mold was considered as the MBC and MFC values, respectively [16].

2.6. Determination of Spore Germination. Spore germination of $P$. digitatum and $A$. flavus was determined following a previously described procedure with modification [17]. $P$. digitatum and $A$. flavus were grown on PDA plates and incubated at $25^{\circ} \mathrm{C}$ and $30^{\circ} \mathrm{C}$, respectively, for 5 days. Spores from each test mold were suspended in $10 \mathrm{ml}$ of sterile water with $5 \%$ glycerol and diluted to provide spore concentrations of $10^{5}$ spores $/ \mathrm{ml}$. The spore suspensions were inoculated into PDA at a final spore concentration of $10^{4}$ spores $/ \mathrm{ml}$. PDA with the mold spores was poured over PDA supplemented with Mao juice at concentrations of 50,100 , or $200 \mathrm{mg} / \mathrm{ml}$. Controls were prepared without fruit juice. PDA inoculated with $P$. digitatum was then incubated at $25^{\circ} \mathrm{C}$ while $A$. flavus was incubated at $30^{\circ} \mathrm{C}$ for 5 days. Periodically, three agar discs were aseptically cut from each agar plate using a sterile cork borer. The discs were placed on a glass slide where spore germination was examined microscopically and considered positive when at least $10 \%$ of the spores had germinated. The lag phase for germination was the number of hours needed for $10 \%$ of the spores to germinate.

2.7. Determination of Total Phenolic Content. Determination of total phenolic content (TPC) was performed in 96-well microplates using Folin-Ciocalteau's method according to Hansakul et al. [18]. A sample $(30 \mu \mathrm{l})$ of fruit juice, $150 \mu \mathrm{l}$ of Folin-Ciocalteau's reagent, and $120 \mu \mathrm{l}$ of $\mathrm{Na}_{2} \mathrm{CO}_{3}$ were added to each well. The plate was incubated at room 
temperature for $30 \mathrm{~min}$. The absorbance was measured at $765 \mathrm{~nm}$. The total phenolic content was expressed as milligrams of gallic acid equivalents per gram of dry juice (mg GAE/g).

2.8. Determination of Total Flavonoid Content. The total flavonoid content (TFC) was measured using aluminum chloride colorimetric assay as reported by Poontawee et al. [19]. A sample $(20 \mu \mathrm{l})$ of fruit juice was added in 96-well microplates. Ethanol $(60 \mu \mathrm{l}), \mathrm{AlCl} 3(10 \mu \mathrm{l}, 10 \%)$, potassium acetate $(10 \mu \mathrm{l}, 1 \mathrm{M})$, and distilled water $(120 \mu \mathrm{l})$ were mixed and added to each well. The plate was incubated at $37^{\circ} \mathrm{C}$ for $30 \mathrm{~min}$ in the dark. The absorbance was determined at $415 \mathrm{~nm}$. The total flavonoid content was expressed as milligrams of quercetin equivalents per gram (mg QE/g).

2.9. Ferric-Reducing Antioxidant Power Assay (FRAP). The reducing capacity of the juice was determined using a ferric-reducing antioxidant power assay (FRAP) assay as described by Hansakul et al. [18]. To prepare the FRAP solution, $300 \mathrm{mM}$ of acetate buffer (pH3.6), $20 \mathrm{mM}$ of ferric chloride hexahydrate, and $10 \mathrm{mM}$ of TPTZ in $40 \mathrm{mM}$ of $\mathrm{HCl}$ were mixed in a ratio of $10: 1: 1$. A sample $(20 \mu \mathrm{l})$ of fruit juice at a concentration of $100 \mu \mathrm{g} / \mathrm{ml}$ was added to 96-well microplates followed by FRAP solution $(180 \mu \mathrm{l})$. The plate was incubated at room temperature for $30 \mathrm{~min}$. The absorbance was measured at $590 \mathrm{~nm}$. The ferricreducing ability was determined from a standard curve of iron (II) sulfate solution and expressed as FRAP ( $\mathrm{mg} \mathrm{Fe}^{2+}$ / g) and TEAC values (mg TE/g).

2.10. DPPH Radical Scavenging Assay. Antioxidant activity was determined using a modified version of the method described by Puangpronpitag et al. [9]. A sample $(100 \mu \mathrm{l})$ of fruit juice at a concentration of $100 \mu \mathrm{g} / \mathrm{ml}$ was added to a 96-well microtiter plate. Then, $300 \mu \mathrm{l}$ of $0.1 \mathrm{mM} \mathrm{2,2-}$ diphenyl-2-picrylhydrazyl (DPPH) in ethanol solution was added to each well. The plate was incubated at $37^{\circ} \mathrm{C}$ for $30 \mathrm{~min}$ in the dark. Absorbance was measured at $517 \mathrm{~nm}$ on a microplate reader. Trolox was used as the positive control, and distilled water was used as the blank. The scavenging activity of the juice against DPPH radicals was expressed as the half maximal effective concentration (EC50; $\mu \mathrm{g} / \mathrm{ml}$ ) and as trolox equivalent antioxidant capacity (TEAC) values (mg TE/g).

2.11. ABTS $^{+}$Radical Scavenging Activity Assay. Antioxidant activity was determined using $\mathrm{ABTS}^{+}$assay as described by Seebaluck-Sandoram et al. [20]. ABTS radical cations $\left(\mathrm{ABTS}^{+}\right.$) were generated by reacting a $7 \mathrm{mM} 2,2^{\prime}$-azino-bis (3-ethylbenzothiazoline-6-sulfonic acid diammonium salt (ABTS) stock solution with $2.45 \mathrm{mM}$ potassium persulfate and keeping overnight in the dark to yield a dark blue solution. The $\mathrm{ABTS}^{+}$radical solution was diluted with ethanol to an absorbance of 0.70 to $0.90 \pm 0.02$ at $734 \mathrm{~nm}$. A sample $(10 \mu \mathrm{l})$ of fruit juice at a concentration of $100 \mu \mathrm{g} / \mathrm{ml}$ was added to $190 \mu \mathrm{l}$ of ABTS cation radical solution in a 96well microplate. The plate was incubated at room temperature for $6 \mathrm{~min}$ in the dark. The absorbance was measure at $734 \mathrm{~nm}$. The scavenging activity of the extracts against
TABle 1: Extraction yield, total phenolic content (TPC), and flavonoid content (TFC) of Mao fruit juice.

\begin{tabular}{lcc}
\hline Extraction yield (\%) & TPC (mg GAE/g) & TFC (mg QE/g) \\
\hline $15.23 \pm 0.81$ & $20.07 \pm 3.43$ & $3.57 \pm 0.96$ \\
\hline
\end{tabular}

Values are shown as mean \pm standard deviation $(n=3)$. GAE: gallic acid equivalent; QE: quercetin equivalent.

$\mathrm{ABTS}^{+}$radicals was expressed as EC50 $(\mu \mathrm{g} / \mathrm{ml})$ and TEAC values (mg TE/g).

2.12. Antimicrobial Activity of Mao Juice in Chiffon Cake. Chiffon cake was prepared using the following ingredients: cake flour, vegetable oil, baking soda, water, sugar, salt, eggs, and potassium tartrate. Five percent of Mao juice was added into the ingredients. After baking at $175^{\circ} \mathrm{C}$ for $20 \mathrm{~min}$, the chiffon cake was placed on a cooling rack until ambient temperature was reached. Then, cake samples were placed in sterile polyethylene bags and stored at $4^{\circ} \mathrm{C}$. The total viable count (TVC) and yeast and mold counts were analyzed at $1,3,5,7$ and 9 days of storage. Twenty-five $g$ of sample were mixed with $225 \mathrm{ml}$ of $0.1 \%$ sterile Butterfield's phosphatebuffered dilution water. Decimal dilutions were prepared of $10^{-2}, 10^{-3}, 10^{-4}$, and others as appropriate by transferring $10 \mathrm{ml}$ of the previous dilution to $90 \mathrm{ml}$ of diluent. Appropriate dilutions were pour plated in plate count agar (PCA) for the determination of TVC. For yeast and mold counts, samples were spread plated in Dichloran 18\% glycerol (DG18). Then, the PCA and DG18 plates were incubated at $35^{\circ} \mathrm{C}$ for 24 hours and at $30^{\circ} \mathrm{C}$ for 5 days, respectively. The microbial counts of chiffon with Mao juice were compared to the control that had no added juice.

2.13. Statistical Analysis. The experiment was performed in triplicate. Results are reported as mean values \pm standard deviation. Microbiological data were transformed into logarithms, expressed as log CFU/g.

\section{Results and Discussion}

3.1. Phytochemical Contents and Antioxidant Activity. The extraction yield of Mao juice was $15.23 \%$ (Table 1). Phytochemical analysis of the Mao juice showed the presence of phenolic compounds and flavonoids. The total phenolic and flavonoid contents were $20.07 \mathrm{mg}$ GAE/g and $3.57 \mathrm{mg}$ $\mathrm{QE} / \mathrm{g}$, respectively. These results were in line with another report where the total phenolic content of Mao fruit juice was $22.67 \mathrm{mg} \mathrm{GAE} / \mathrm{g}$ [3]. There has been little reporting of the flavonoid content in Mao juice; however, Chinprahast et al. [21] found that total flavonoid contents in Mao fruit extracts with different solvents ranged from 18.45 to $255.16 \mathrm{mg}$ QE/100 g. Krongyut and Sutthanut [22] also reported that the ethanolic extract of Mao ripe fruits, yield $12.08 \%$, contained phenolics (11.6 mg GAE/g extract) and flavonoids (0.30 QE/g extract). Butkhup and Samappito [8] reported that gallic acid and (+)-catechin were the main phenolic acid and flavonoid, respectively, found in Mao berries. Three complementary tests (DPPH, $\mathrm{ABTS}^{+}$free radical-scavenging activity, and reducing power assay) were 
TABLE 2: Antioxidant activity of Mao fruit juice determined using DPPH, $\mathrm{ABTS}^{+}$, and FRAP testing.

\begin{tabular}{|c|c|c|c|c|c|c|}
\hline \multirow[b]{2}{*}{ Sample } & \multicolumn{2}{|c|}{ DPPH scavenging activity } & \multicolumn{2}{|c|}{$\mathrm{ABTS}^{+}$scavenging activity } & \multicolumn{2}{|c|}{$\begin{array}{c}\text { Ferric-reducing antioxidant } \\
\text { power }\end{array}$} \\
\hline & $\begin{array}{c}\mathrm{EC}_{50} \\
(\mu \mathrm{g} / \mathrm{ml})\end{array}$ & $\begin{array}{l}\text { TEAC value } \\
\text { (mg TE/g) }\end{array}$ & $\begin{array}{c}\mathrm{EC}_{50} \\
(\mu \mathrm{g} / \mathrm{ml})\end{array}$ & $\begin{array}{l}\text { TEAC value } \\
\text { (mg TE/g) }\end{array}$ & $\begin{array}{l}\text { FRAP value } \\
\left(\mathrm{mg} \mathrm{Fe}^{2+} / \mathrm{g}\right)\end{array}$ & $\begin{array}{l}\text { TEAC value } \\
\text { (mg TE/g) }\end{array}$ \\
\hline Juice & $72.18 \pm 1.90$ & $475.11 \pm 12.52$ & $76.95 \pm 3.66$ & $569.90 \pm 26.57$ & $184.59 \pm 3.44$ & $90.59 \pm 1.69$ \\
\hline Trolox & $34.26 \pm 0.55$ & - & $43.76 \pm 0.82$ & - & $203.76 \pm 5.44$ & - \\
\hline
\end{tabular}

Values are shown as mean \pm standard deviation $(n=3)$. DPPH: 2, 2-diphenyl-2-picrylhydrazyl; ABTS: 2,2' -azino-bis (3-ethylbenzothiazoline-6-sulfonic acid) diammonium salt; FRAP: ferric-reducing antioxidant power; $\mathrm{EC}_{50}$ : half maximal effective concentration; TEAC: trolox equivalent antioxidant capacity; TE: trolox equivalent.

TABle 3: Inhibition zones related to MIC using different Mao fruit juice concentrations.

\begin{tabular}{|c|c|c|c|c|c|c|c|c|}
\hline \multirow{2}{*}{ Juice (mg/ml) } & \multicolumn{8}{|c|}{ Inhibition zone $(\mathrm{mm})$} \\
\hline & B. cereus & S. aureus & L. monocytogenes & E. coli & P. aeruginosa & S. Typhimurium & A. flavus & P. digitatum \\
\hline 25 & $0.00 \pm 0.00$ & $0.00 \pm 0.00$ & $9.55 \pm 0.48$ & $0.00 \pm 0.00$ & $0.00 \pm 0.00$ & $0.00 \pm 0.00$ & $0.00 \pm 0.00$ & $0.00 \pm 0.00$ \\
\hline 50 & $6.29 \pm 0.26$ & $6.03 \pm 0.02$ & $21.55 \pm 0.48$ & $11.65 \pm 1.02$ & $0.00 \pm 0.00$ & $11.42 \pm 1.02$ & $10.31 \pm 1.36$ & $16.58 \pm 0.59$ \\
\hline 100 & $8.73 \pm 0.64$ & $7.03 \pm 0.43$ & $24.83 \pm 0.45$ & $17.61 \pm 1.19$ & $9.36 \pm 1.28$ & $18.61 \pm 0.67$ & $12.01 \pm 1.07$ & $20.43 \pm 0.70$ \\
\hline 200 & $9.90 \pm 0.99$ & $9.48 \pm 0.60$ & $26.97 \pm 1.52$ & $20.08 \pm 1.15$ & $11.41 \pm 1.86$ & $21.06 \pm 0.80$ & $13.65 \pm 0.49$ & $24.24 \pm 2.60$ \\
\hline Gentamycin & $17.52 \pm 0.76$ & $16.43 \pm 1.59$ & $18.83 \pm 1.11$ & $26.05 \pm 0.38$ & $11.75 \pm 0.93$ & $22.99 \pm 0.23$ & - & - \\
\hline Amphotericin B & - & - & - & - & - & - & $7.99 \pm 1.25$ & $10.08 \pm 2.31$ \\
\hline \multirow{2}{*}{ Juice $(\mathrm{mg} / \mathrm{ml})$} & \multicolumn{8}{|c|}{$\mathrm{MIC}(\mathrm{mg} / \mathrm{ml})$} \\
\hline & 50 & 50 & 25 & 50 & 100 & 50 & 50 & 50 \\
\hline
\end{tabular}

used to assess the antioxidant activity in the Mao juice, and the results are presented in Table 2 . The juice had radical scavenging activity against both DPPH radicals $(\mathrm{EC} 50=$ $72.18 \mu \mathrm{g} / \mathrm{ml}$ ) and $\mathrm{ABTS}^{+}$radicals $(\mathrm{EC} 50=76.95 \mu \mathrm{g} / \mathrm{ml})$. The FRAP value was $184.59 \mathrm{mg} \mathrm{Fe} / \mathrm{g}$. The juice had moderate antioxidant power compared to the positive standard trolox. Antioxidant activity is significantly correlated with the phenolic compounds found in a plant $[6,20]$, and the antioxidant activity of phenolic compounds is attributed to their donating electron, scavenging free radicals, and reducing power [23]. The antioxidant activity of fruit juices is the synergistic effect of different antioxidants existing in the juice [24]. Hardinasinta et al. [12] reported that Mao juice has relatively high antioxidant activity, and significant correlation was found between the antioxidant capacity and some polyphenolic compounds. The antioxidant activity of Mao fruits is related to gallic acid, ferulic acid, and some anthocyanins, mainly cyanidin-3-O-glucoside [6].

3.2. Determination of Antimicrobial Activity. The antimicrobial activities of Mao juice were tested against different food spoilage organisms and foodborne pathogens. Mao juice had antibacterial activity against all bacterial strains, namely, three strains of Gram-positive (B. cereus, S. aureus, and L. monocytogenes) and three strains of Gram-negative (S. Typhimurium, $P$. aeruginosa, and E. coli) (as shown in Table 3). L. monocytogenes was the most sensitive to the Mao juice with an inhibition zone of $26.97 \mathrm{~mm}$. The MIC for L. monocytogenes was $25 \mathrm{mg} / \mathrm{ml}$, with a higher MIC of $50 \mathrm{mg} / \mathrm{ml}$ for B. cereus, S. aureus, S. Typhimurium, and $E$. coli. The antibacterial activity of plant extracts has been attributed to individual phenolic compounds [25-27]. Plants containing phenols, tannins, and flavonoids are effective against bacterial species [28]. The biological activity is related to their molecular structure (hydroxyl group or phenolic ring) resulting in phenolic compounds having the capacity to attach proteins and bacterial membrane to form a complex [29]. Phenolic compounds have been reported to have varying antimicrobial activity against foodborne pathogens. The current study showed that Gram-positive bacteria were more susceptible to Mao juice than Gram-negative bacteria. Other researchers have also suggested that natural antimicrobial substances, such as essential oils and extracts were more active against Gram-positive bacteria than Gram-negative bacteria [30, 31]. Notably, the Mao juice had antifungal activity against $A$. flavus and $P$. digitatum, with inhibition zone diameters of 13.65 and $24.24 \mathrm{~mm}$, respectively, and MIC value of $50 \mathrm{mg} / \mathrm{ml}$. Antifungal growth was observed as a clear circular zone of inhibition. Furthermore, in the current study, Mao juice retarded the germination of P. digitatum conidia. Mold spores in the control agar germinated after $32 \mathrm{~h}$ of incubation at $25^{\circ} \mathrm{C}$, while no germination occurred in the presence of the fruit juice at concentrations of $50-200 \mathrm{mg} / \mathrm{ml}$ (Table 4). Spore germination of $P$. digitatum was observed in the test with fruit juice after $72 \mathrm{~h}$ of incubation. The lag phase for germination of $P$. digitatum increased from 24 hour to 48 hours. Fungal strains differ in their susceptibility to plant extract [32], as shown in the current study where Mao fruit juice was unable to inhibit spore germination of A. flavus. Natural extracts have different effects on fungal growth. Mohammedi and Atik [33] reported that extracts from D. gnidium exhibited 
Table 4: Effect of Mao fruit juice on spore germination of A. flavus and P. digitatum.

\begin{tabular}{|c|c|c|c|c|c|c|c|c|}
\hline \multirow{3}{*}{ Incubation time $(\mathrm{h})$} & \multicolumn{8}{|c|}{ Spore germination } \\
\hline & \multicolumn{2}{|c|}{ Control } & \multicolumn{2}{|c|}{$50 \mathrm{mg} / \mathrm{ml}$} & \multicolumn{2}{|c|}{$100 \mathrm{mg} / \mathrm{ml}$} & \multicolumn{2}{|c|}{$200 \mathrm{mg} / \mathrm{ml}$} \\
\hline & A. flavus & P. digitatum & A. flavus & P. digitatum & A. flavus & P. digitatum & A. flavus & P. digitatum \\
\hline 0 & - & - & - & - & - & - & - & - \\
\hline 8 & - & - & - & - & - & - & - & - \\
\hline 16 & + & - & + & - & + & - & + & - \\
\hline 24 & + & - & + & - & + & - & + & - \\
\hline 32 & + & + & + & - & + & - & + & - \\
\hline 48 & + & + & + & - & + & - & + & - \\
\hline 72 & + & + & + & + & + & + & + & + \\
\hline 80 & + & + & + & + & + & + & + & + \\
\hline
\end{tabular}

+: at least $10 \%$ of mold spores had germinated.

Table 5: Microbial count of chiffon cake during storage at $4^{\circ} \mathrm{C}$ for 9 days.

\begin{tabular}{lccc}
\hline Samples & $\begin{array}{c}\text { Period } \\
\text { (days) }\end{array}$ & $\begin{array}{c}\text { Total plate count } \\
(\log \text { CFU/g) }\end{array}$ & $\begin{array}{c}\text { Yeast and } \\
\text { mold count } \\
(\log \text { CFU/g) }\end{array}$ \\
\hline & 1 & 1.74 & 1.74 \\
Untreated chiffon cake & 3 & 1.30 & 1.32 \\
& 5 & 2.23 & 2.40 \\
& 9 & 2.34 & 2.59 \\
Chiffon cake with & 3 & 2.60 & 2.57 \\
5\% Mao fruit juice & 5 & 1.58 & 1.60 \\
& 7 & 2.08 & 1.00 \\
& 9 & 2.60 & 1.85 \\
& & 3.04 & 1.48 \\
\hline
\end{tabular}

complete inhibitory effect on mycelium growth and spore germination of $A$. flavus, while $H$. scoparium exhibited inhibitory effect only on spore germination. Fresh leaf extracts of Flourensia cernua caused reduction in the colony growth of Alternaria alternata, P. digitatum, and Colletrotichum gloeosporiodes; however, the extracts had no effect on the sporulation [34]. The antifungal activity of plants has been related to bioactive compounds with the principal groups being alkaloids, anthraquinones, flavonoids, and tannins [35]. The microcidal effect was also examined in this study; however, the juice had no bactericidal and fungicidal activity against any of the tested microorganisms. Nonetheless, the results showed that Mao juice had strong antibacterial and antifungal properties. This observation differed somewhat from Dechayont et al. [3] who, using a disc diffusion method, reported that the juice at a concentration of $5 \mathrm{mg}$ per disc had no antimicrobial activity against $S$. aureus, E. coli, or $S$. Typhimurium. Differences between the studies may have been related to many experimental variances such as concentrations of the extracts, bacterial strains, and the methodology applied for assay. Similar negative results were reported for other fruit juices such as cranberry, with Côté et al. [36] reporting that cranberry juice had no antibacterial effect against $L$. monocytogenes HPB, E. coli O157:H7 EDL 933, E. coli
ATCC 25922, 2812, S. Typhimurium SL1344, S. aureus, and $P$. aeruginosa ATCC 15442. In contrast, Harich et al. [37] found that cranberry juice had antibacterial activity against Gram-positive L. monocytogenes and the Gramnegative pathogenic bacteria $S$. typhimurium and E. coli O157:H7. In the current study, Mao juice did not have any microcidal activity against any of the tested bacteria and molds, suggesting that perhaps a higher concentration is required to achieve mortality. Fatmawati et al. [38] also reported that the antimicrobial effect increased with an increase in the concentration of the fruit extract. For this reason, Mao juice in the concentration range $25-200 \mathrm{mg} /$ $\mathrm{ml}$ is supposed to be a microstatic antimicrobial against both bacteria and mold.

3.3. Application of Mao Juice in Chiffon Cake. Bakery products are intermediate moisture foods and are mainly spoiled by yeasts and filamentous fungi. Saeed et al. [39] reported that A. niger, A. flavus, A. fumigatus, A. terreus, Alternaria alternata, Curvularia americana, Fusarium solani, $P$. digitatum, Saccharomyces cerevisiae, and Geotrichum candidum were found in bakery samples. In the current study, the efficacy of the fruit juice in controlling microbial growth in chiffon cake was examined for 9 days at $4^{\circ} \mathrm{C}$ storage. Results showed that all samples had increasing TVCs during refrigerated storage (Table 5). However, TVC was lower than the value of $4.0 \mathrm{log} \mathrm{CFU} / \mathrm{g}$, which was considered as the upper microbiological limit for bakery products, as defined by the Ministry of Public Health (Thailand). However, yeast and mold counts were higher than the permissible limit of $2.0 \mathrm{log}$ $\mathrm{CFU} / \mathrm{g}$ on day 5 for untreated chiffon cake. The results showed that the addition of $5 \%$ fruit juice significantly inhibited the growth of yeast and mold in a baked product. The shelf-life of treated sample was extended to 7 days that was over double the 3 days for untreated chiffon cake. The study demonstrated the potential application of Mao juice as an ingredient in chiffon cake to inhibit yeast and mold. The results indicate its potential as a natural food preservative in a baked product.

\section{Conclusions}

This study revealed that Antidesma thwaitesianum Müll. Arg. (Mao) fruit juice had antimicrobial activity against food 
spoilage organisms and food borne pathogens. The present study is the first report on the antifungal activity of Mao fruit juice against Aspergillus flavus TISTR3135 and Penicillium digitatumATCC10030. Mao fruit juice contains bioactive compounds and demonstrated antioxidant capacity. The antimicrobial efficacy of Mao fruit juice showed that it could be used as a natural promising preservative, which could extend the shelf life of a bakery product to 7 days.

\section{Data Availability}

All the data relevant to the research are included in the manuscript. Any further information required is available from the corresponding author upon request.

\section{Conflicts of Interest}

The authors declare no conflict of interest.

\section{Acknowledgments}

This research was supported by the Faculty of Natural Resources and Agro-Industry, Chalermphrakiat Sakon Nakhon Province Campus and the Kasetsart University Research and Development Institute (KURDI), Kasetsart University, Thailand.

\section{References}

[1] P. Hoffmann, Antidesma in Malesia and Thailand, Royal Botanic Gardens, United Kingdom, 2005.

[2] M. Shariful Islam, M. Sharif Ahammed, F. Islam Sukorno, S. Ferdowsy Koly, M. Morad Biswas, and S. Hossain, "A review on phytochemical and pharmacological potentials of Antidesma bunius," Journal of Analytical \& Pharmaceutical Research, vol. 7, no. 5, pp. 602-604, 2018.

[3] B. Dechayont, P. Hansakul, and A. Itharat, "Comparison of antimicrobial, antioxidant activities and total phenolic content of Antidesma thwaitesianum fruit extracts by different methods," Journal Medical association of Thailand, vol. 95, Supplement 1, pp. S147-S153, 2012.

[4] P. Pongnaratorn, P. Kuacharan, V. Kotsuno, N. Pakdee, P. Sriraj, and J. Sattayasai, "In vitro antimicrobial activity of Antidesma bunius extracts on oral pathogenic bacteria," Thai Journal of Pharmaceutical Sciences, vol. 41, no. 4, pp. 144149, 2017.

[5] Y. Yelliantty, R. E. Kartasasmita, S. I. Surantaatmadja, and Y. Rukayadi, "Identification of chemical constituents from fruit of Antidesma bunius by GC-MS and HPLC-DAD-ESIMS," Food Science and Technology, 2021.

[6] S. Jorjong, L. Butkhup, and S. Samappito, "Phytochemicals and antioxidant capacities of Mao-Luang (Antidesma bunius L.) cultivars from Northeastern Thailand," Food Chemistry, vol. 181, pp. 248-255, 2015.

[7] J. R. Micor, C. C. Deocaris, and E. R. Mojica, "Biological activity of bignay [Antidesma bunius (L.) Spreng] crude extract in Artemia salina," Journal of Medical Sciences, vol. 5, no. 3, pp. 195-198, 2005.

[8] L. Butkhup and S. Samappito, "Analysis of anthocyanin, flavonoids, and phenolic acids in tropical bignay berries," International Journal of Fruit Science, vol. 8, no. 1-2, pp. 15-34, 2008.
[9] D. Puangpronpitag, P. Areejitranusorn, P. Boonsiri, M. Suttajit, and P. Yongvanit, "Antioxidant activities of polyphenolic compounds isolated from Antidesma thwaitesianum Müll. Arg. seeds and marcs," Journal of Food Science, vol. 73, no. 9, pp. C648-C653, 2008.

[10] P. Chaikham, "Comparison of high hydrostatic pressure and thermal processing on physicochemical and antioxidant properties of Maoberry (Antidesma thwaitesianum Müell. Arg.) juice," International Food Research Journal, vol. 22, no. 5, pp. 1993-2001, 2015.

[11] T. Sripakdee, A. Sriwicha, N. Jansam, R. Mahachai, and S. Chanthai, "Determination of total phenolics and ascorbic acid related to an antioxidant activity and thermal stability of the Mao fruit juice," International Food Research Journal, vol. 22, no. 2, pp. 618-624, 2015.

[12] G. Hardinasinta, M. Mursalim, J. Muhidong, and S. Salengke, "Determination of some chemical compounds of bignay (Antidesma bunius) fruit juice," Food Science and Technology, vol. 41, no. 4, pp. 974-979, 2021.

[13] R. C. Lizardo, L. B. Mabesa, E. I. Dizon, and N. A. Aquino, "Functional and antimicrobial properties of bignay [Antidesma bunius (L.) Spreng.] extract and its potential as natural preservative in a baked product," International Food Research Journal, vol. 22, pp. 88-95, 2015.

[14] N. S. Al-Zoreky, "Antimicrobial activity of pomegranate (Punica granatum L.) fruit peels," International Journal of Food Microbiology, vol. 134, no. 3, pp. 244-248, 2009.

[15] F. D. Gonelimali, J. Lin, W. Miao et al., "Antimicrobial properties and mechanism of action of some plant extracts against food pathogens and spoilage microorganisms," Frontiers in Microbiology, vol. 9, p. 1639, 2018.

[16] R. Mogana, A. Adhikari, M. Tzar, R. Ramliza, and C. Wiart, "Antibacterial activities of the extracts, fractions and isolated compounds from Canarium patentinervium Miq. against bacterial clinical isolates," BMC Complementary Medicine and Therapies, vol. 20, no. 1, pp. 1-11, 2020.

[17] M. A. Passone, S. Resnik, and M. G. Etcheverry, "In vitro effect of phenolic antioxidants on germination, growth and aflatoxin B1 accumulation by peanut Aspergillus section Flavi," Journal of Applied Microbiology, vol. 99, no. 3, pp. 682-691, 2005.

[18] P. Hansakul, B. Dechayont, P. Phuaklee, O. Prajuabjinda, T. Juckmeta, and A. Itharat, "Cytotoxic and antioxidant activities of Antidesma thwaitesianum Müll Arg (Euphorbiaceae) fruit and fruit waste extracts," Tropical Journal of Pharmaceutical Research, vol. 14, no. 4, pp. 627-634, 2015.

[19] W. Poontawee, S. Natakankitkul, and O. Wongmekiat, "Enhancing phenolic contents and antioxidant potentials of Antidesma thwaitesianum by supercritical carbon dioxide extraction," Journal of Analytical Methods in Chemistry, vol. 2015, 7 pages, 2015.

[20] R. Seebaluck-Sandoram, N. Lall, B. Fibrich, A. Blom van Staden, and F. Mahomoodally, "Antibiotic-potentiation, antioxidant, cytotoxic, anti-inflammatory and anti- acetylcholinesterase potential of Antidesma madagascariense Lam. (Euphorbiaceae)," South African Journal of Botany, vol. 111, pp. 194-201, 2017.

[21] N. Chinprahast, J. Boonying, and N. Popuang, "Antioxidant activities of mamao luang (Antidesma thwaitesianum Müll. Arg.) fruit: extraction and application in raw chicken patties," Journal of Food Science, vol. 85, no. 3, pp. 647-656, 2020.

[22] O. Krongyut and K. Sutthanut, "Phenolic profile, antioxidant activity, and anti-obesogenic bioactivity of Mao Luang fruits 
(Antidesma bunius L.)," Molecules, vol. 24, no. 22, p. 4109, 2019.

[23] M. Embuscado and F. Shahidi, "Handbook of antioxidants for food preservation," in A volume in Woodhead Publishing Series in Food Science, pp. 251-283, UK: Technology and Nutrition, 2015.

[24] M. Ramadan and J. T. Moersel, "Impact of enzymatic treatment on chemical composition, physicochemical properties and radical scavenging activity of goldenberry (Physalis peruviana L.) juice," Journal of the Science of Food and Agriculture, vol. 87, no. 3, pp. 452-460, 2007.

[25] G. Jayaprakasha, T. Selvi, and K. Sakariah, "Antibacterial and antioxidant activities of grape (Vitis vinifera) seed extracts," Food Research International, vol. 36, no. 2, pp. 117-122, 2003.

[26] G. Özkan, O. Sagdiç, N. Göktürk Baydar, and Z. Kurumahmutoglu, "Antibacterial activities and total phenolic contents of grape pomace extracts," Journal of the Science of Food and Agriculture, vol. 84, no. 14, pp. 1807-1811, 2004.

[27] S. Sakanaka, L. R. Juneja, and M. Taniguchi, "Antimicrobial effects of green tea polyphenols on thermophilic sporeforming bacteria," Journal of Bioscience and Bioengineering, vol. 90, no. 1, pp. 81-85, 2000.

[28] I. Ahmad and A. Z. Beg, "Antimicrobial and phytochemical studies on 45 Indian medicinal plants against multi-drug resistant human pathogens," Journal of Ethnopharmacology, vol. 74, no. 2, pp. 113-123, 2001.

[29] R. Puupponen-Pimia, L. Nohynek, C. Meier et al., "Antimicrobial properties of phenolic compounds from berries," Journal of Applied Microbiology, vol. 90, no. 4, pp. 494-507, 2001.

[30] S. Burt, "Essential oils: their antibacterial properties and potential applications in foods-a review," International Journal of Food Microbiology, vol. 94, no. 3, pp. 223-253, 2004.

[31] E. A. Palombo and S. J. Semple, "Antibacterial activity of traditional Australian medicinal plants," Journal of Ethnopharmacology, vol. 77, no. 2-3, pp. 151-157, 2001

[32] A. A. Shahat, E. A. Mahmoud, A. A. Al-Mishari, and M. S. Alsaid, "Antimicrobial activities of some Saudi Arabian herbal plants," African Journal of Traditional, Complementary and Alternative Medicines, vol. 14, no. 2, pp. 161-165, 2017.

[33] Z. Mohammedi and F. Atik, "Fungitoxic effect of natural extracts on mycelial growth, spore germination and aflatoxin B1 production of Aspergillus flavus," Australian Journal of Crop Science, vol. 7, no. 3, pp. 293-298, 2013.

[34] E. Guerrero-Rodríguez, S. Solís-Gaona, F. D. Hernández-Castillo, A. Flores-Olivas, V. Sandoval-López, and D. Jasso-Cantú, "Actividad biológica in vitro de extractos de Fluorensia cernua D.C. en patógenos de postcosecha: Alternaria alternata (Fr.: Fr.) Keissl., Colletotrichum gloeosporioides (Penz.) Penz. y Sacc. y Penicillium digitatum (Pers.: Fr.) Sacc," Revista Mexicana de Fitopatología, vol. 25, pp. 48-53, 2007.

[35] H. Zanna, Y. Tijani, S. Abubakar, B. Modu, A. A. Damasak, and S. M. Uzairu, "Fungicidal potential of selected plant extracts against human pathogenic fungi," Scientific African, vol. 13, p. e00864, 2021.

[36] J. Côté, S. Caillet, G. Doyon, D. Dussault, J. F. Sylvain, and M. Lacroix, "Antimicrobial effect of cranberry juice and extracts," Food Control, vol. 22, no. 8, pp. 1413-1418, 2011.

[37] M. Harich, B. Maherani, S. Salmieri, and M. Lacroix, "Antibacterial activity of cranberry juice concentrate on freshness and sensory quality of ready to eat (RTE) foods," Food Control, vol. 75, pp. 134-144, 2017.
[38] D. R. Fatmawati and A. Pangastuti, "Susilowati use of edible film incorporated with Parijoto fruit extract (Medinilla speciosa Blume) to inhibit microbiological and oxidative damages of sausages," Applied Food Biotechnology, vol. 8, no. 4, pp. 319328,2021

[39] I. Saeed, S. Shaheen, K. Hussain et al., "Assessment of mold and yeast in some bakery products of Lahore, Pakistan based on LM and SEM," Microscopy Research and Technique, vol. 82, no. 2, pp. 85-91, 2019. 